\title{
Efficient production of immunologically active Shigella invasion plasmid antigens IpaB and IpaH using a cell-free expression system
}

\author{
Neeraj Kapoor ${ }^{1}\left[\right.$ - Esther Ndungo ${ }^{2} \cdot$ Lucy Pill $^{1} \cdot$ Girmay Desalegn $^{2} \cdot$ Aym Berges $^{1} \cdot$ Edwin V. Oaks $^{3}$. Jeff Fairman ${ }^{1}$. \\ Marcela F. Pasetti ${ }^{2}$
}

Received: 23 September 2021 / Revised: 15 November 2021 / Accepted: 18 November 2021 / Published online: 21 December 2021

(c) The Author(s) 2021

\begin{abstract}
Shigella spp. invade the colonic epithelium and cause bacillary dysentery in humans. Individuals living in areas that lack access to clean water and sanitation are the most affected. Even though infection can be treated with antibiotics, Shigella antimicrobial drug resistance complicates clinical management. Despite decades of effort, there are no licensed vaccines to prevent shigellosis. The highly conserved invasion plasmid antigens (Ipa), which are components of the Shigella type III secretion system, participate in bacterial epithelial cell invasion and have been pursued as vaccine targets. However, expression and purification of these proteins in conventional cell-based systems have been challenging due to solubility issues and extremely low recovery yields. These difficulties have impeded manufacturing and clinical advancement. In this study, we describe a new method to express Ipa proteins using the Xpress ${ }^{+\mathrm{TM}}$ cell-free protein synthesis (CFPS) platform. Both IpaB and the C-terminal domain of IpaH1.4 (IpaH-CTD) were efficiently produced with this technology at yields $>200 \mathrm{mg} / \mathrm{L}$. Furthermore, the expression was linearly scaled in a bioreactor under controlled conditions, and proteins were successfully purified using multimode column chromatography to $>95 \%$ purity as determined by SDS-PAGE. Biophysical characterization of the cell-free synthetized IpaB and IpaH-CTD using SEC-MALS analysis showed well-defined oligomeric states of the proteins in solution. Functional analysis revealed similar immunoreactivity as compared to antigens purified from $E$. coli. These results demonstrate the efficiency of CFPS for Shigella protein production; the practicality and scalability of this method will facilitate production of antigens for Shigella vaccine development and immunological analysis.
\end{abstract}

\section{Key points}

- First report of Shigella IpaB and IpaH produced at high purity and yield using CFPS

- CFPS-IpaB and IpaH perform similarly to E. coli-produced proteins in immunoassays

- CFPS-IpaB and IpaH react with Shigella-specific human antibodies and are immunogenic in mice.

Keywords Shigella $\cdot$ Cell-free protein synthesis $\cdot$ Vaccine $\cdot$ Invasion plasmid antigens

Neeraj Kapoor

neeraj.kapoor@vaxcyte.com

Jeff Fairman

jeff.fairman@vaxcyte.com

$\triangle$ Marcela F. Pasetti

mpasetti@som.umaryland.edu

1 Vaxcyte, Inc., 353 Hatch Dr, Foster City, CA 94404, USA

2 Center for Vaccine Development and Global Health, University of Maryland School of Medicine, 685 W. Baltimore Street, Baltimore, MD 21201, USA

3 Patuxent Research and Consulting Group, Gambrills, MD, USA

\section{Introduction}

Shigella spp. are a leading cause of moderate to severe diarrhea in young children living in low- and middle-income countries and the second cause of diarrheal mortality among all ages (Khalil et al. 2018; Kotloff et al. 2019; Livio et al. 2014). Shigella invasion, replication, and spread within the colonic epithelium result in acute dysentery (bloody, mucoidal diarrhea). Although antibiotic treatment can limit the disease, the increased prevalence of antibiotic resistance among Shigella isolates demands improved preventive measures including better hygiene, clean water, and pathogen-specific immunity. Efforts to produce Shigella vaccines 
have been ongoing for decades, and yet a safe and effective vaccine has not materialized. A hindrance to this endeavor has been the incomplete understanding of bacterial pathogenesis, the underlying mechanisms of host defenses, and antigen specificity required for protective immunity. Several vaccine candidates are in various clinical stages of development (Walker et al. 2021), most of which rely on generating immunity against the Shigella $\mathrm{O}$-antigen. The O-antigen vaccine concept stems from epidemiological evidence of antibody-associated O-serotype-specific protection (Cohen et al. 1991; Cohen et al. 2019; Robin et al. 1997). A logistic drawback of this approach is the need for multiple O-antigen vaccine components to prevent disease caused by different circulating serotypes. In addition, bacterial polysaccharides require bystander $\mathrm{T}$ helper-inducing molecules to generate strong and long-lasting adaptive immunity (Avci et al. 2019; Rappuoli 2018). These requirements increase complexity of manufacturing and cost. Other major vaccine targets are the conserved invasion plasmid antigen (Ipa) proteins (Fig. 1) (Heine et al. 2013; Martinez-Becerra et al. 2013a; MartinezBecerra et al. 2012; Riddle et al. 2011; Turbyfill et al. 2018). The Ipa proteins are part of the Shigella type III secretion system (T3SS), a molecular machine that injects bacterial virulence effectors into host cells (Fig. 1) (Bajunaid et al. 2020; Schnupf and Sansonetti 2019; Schroeder and Hilbi 2008), a critical initial step in Shigella invasion of colonic epithelial cells.

IpaB is a $62 \mathrm{kDa}$ hydrophobic protein highly conserved among Shigella species (homology $>98 \%$ ) that functions as a T3SS translocator and effector. It is synthesized in the bacterial cytoplasm, complexed with its cognate chaperone $\mathrm{IpgC}$, recruited after IpaD to the needle tip, and eventually secreted as a complex with IpaC that forms a pore in the host cell membrane (Fig. 1). IpaB interaction with the host cell membrane is required for Shigella invasion. IpaB is also critical in the process by which Shigella escape from the phagosome and enter the host cell cytoplasm and is responsible for apoptosis of phagocytic cells (Mattock and Blocker 2017; Schnupf and Sansonetti 2019; Schroeder and Hilbi 2008). Antibodies to IpaB are prominent in infected individuals living in endemic areas and in subjects orally immunized with live attenuated strains (Ndungo et al. 2018; Oaks et al. 1986; Oberhelman et al. 1991; Van de Verg et al. 1992). IpaB-specific IgG (IgG1) titers have been associated with clinical protection against shigellosis in experimentally infected human volunteers (Shimanovich et al. 2017). Several Shigella vaccine candidates based on IpaB have been evaluated in animal models (Chitradevi et al. 2015; Chitradevi et al. 2016; Heine et al. 2014; Heine et al. 2013; Martinez-Becerra et al. 2012; MartinezBecerra et al. 2013b). Despite the encouraging proof of principle efficacy in pre-clinical studies, IpaB has never been evaluated in humans as a purified vaccine candidate.

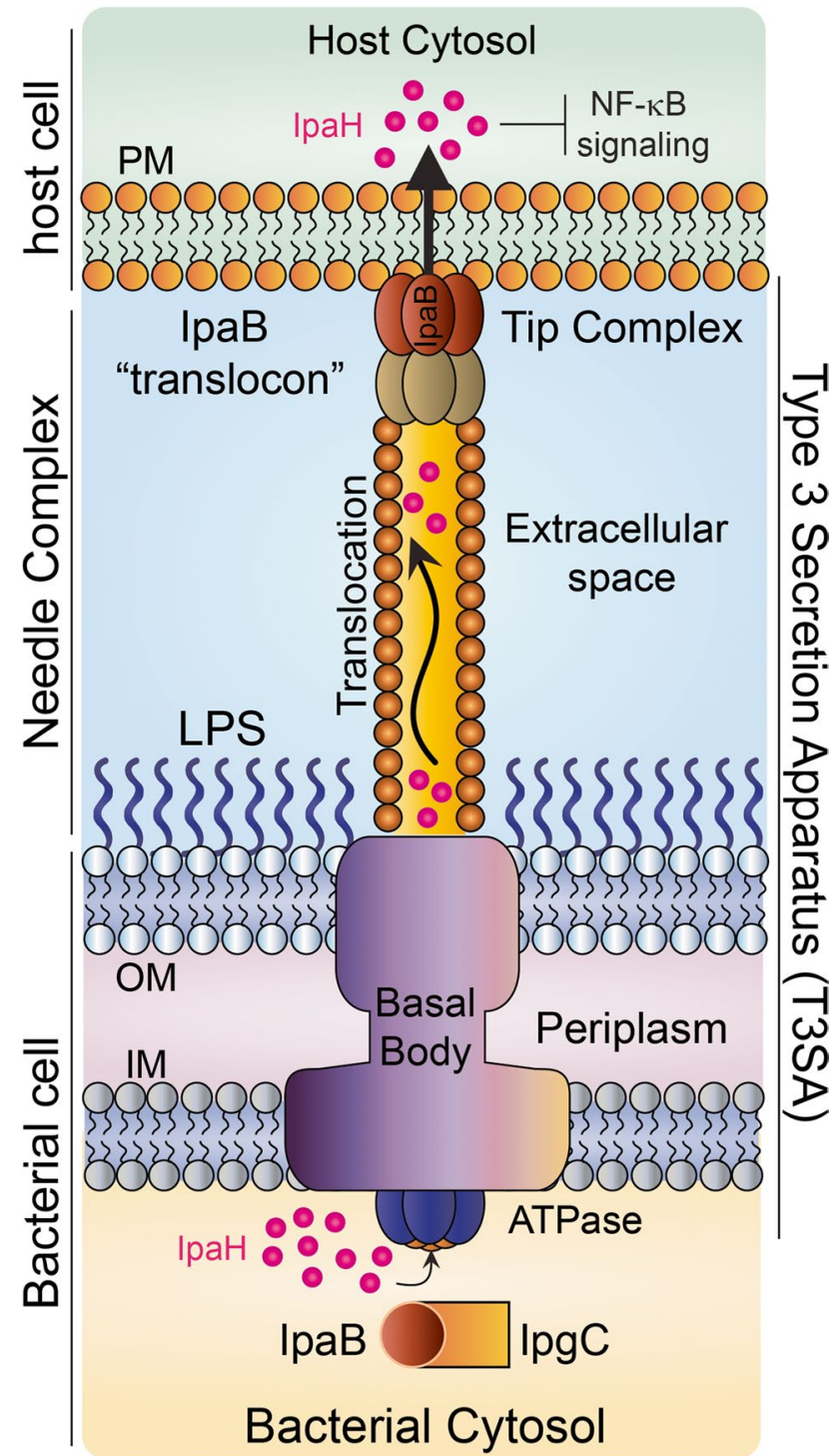

Fig. 1 Schematic representation of the Shigella type III secretion apparatus (T3SA) and role of IpaB and IpaH proteins. IpaB binds to its cognate chaperone IpgC in the bacterial cytosol. Shigella T3SA extends from the bacterial inner and outer membrane and across the periplasm to form a pore into the host cell plasma membrane. At the tip of this injection needle, IpaB assembles into a pore-forming oligomeric translocon that facilitates delivery of virulence factors. The IpaH family of proteins are effectors secreted through the T3SA and are involved in modulating host immune responses. IpaH suppresses $\mathrm{NF}-\kappa \mathrm{B}$ activation, which downregulates inflammatory responses

The Ipa proteins have been traditionally difficult to produce at large scale due to solubility and yield issues. IpaB has been purified post expression in $E$. coli with only moderate yields (1-2 mg/L culture) (Picking et al. 1996), and the low solubility of the protein requires co-expression of its cognate chaperone $\mathrm{IpgC}$, which is a limiting factor in cellbased expression systems (Birket et al. 2007; Dickenson et al. 2013). 
The IpaH family of proteins, which are also T3SS effector proteins, are widely conserved among Shigella and/or other closely related bacteria (Ashida and Sasakawa 2015). IpaH proteins contain an $\mathrm{N}$-terminal leucine-rich repeat and a C-terminal region with E3 ubiquitin ligase activity (Ashida et al. 2007). While the $\mathrm{N}$-terminal domain varies among IpaH proteins (encoded by either the chromosome or virulence plasmid), the C-terminal domain (IpaH-CTD) is conserved between isoforms and Shigella species (Ashida and Sasakawa 2015). IpaH-CTD has been shown to possess E3 ubiquitin ligase activity which promotes bacterial survival by triggering macrophage killing and dampening the host immune responses through NF- $\mathrm{KB}$ inhibition (Ashida and Sasakawa 2015; Rohde et al. 2007; Singer et al. 2008). ipaH genes are present in the genomes of all Shigella species and thus have long been used as targets in molecular diagnostics of Shigella and/or the closely related enteroinvasive E. coli (EIEC) in fecal samples (Lindsay et al. 2013; Liu et al. 2016; Sahl et al. 2015; Venkatesan et al. 1989; Vu et al. 2004). Nonetheless, evidence of immunogenicity of IpaH had been limited until recently when our group demonstrated human serum antibody reactivity to IpaH in a novel microarray system (Ndungo et al. 2018). Functional and structural studies on IpaH have been performed with purified IpaH or portions of IpaH (Ye et al. 2020), and as with IpaB, these studies report production of small quantities of protein using traditional research-scale recombinant methods.

A Shigella vaccine based on shared proteins is appealing for its simplicity and, unlike the O-antigen-based counterparts, can broaden effectiveness against multiple Shigella serotypes. New technologies for simple and efficient production of protein vaccine candidates are necessary to eventually achieve a scalable product that can be manufactured consistently and clinically evaluated. Here, we describe the adaptation and optimization of the Xpress ${ }^{+\mathrm{TM}}$ cell-free protein synthesis (CFPS) platform to express and purify high yields of full-length IpaB and IpaH-CTD (i.e., C-terminal domain of IpaH1.4). The Xpress ${ }^{+\mathrm{TM}}$ CFPS (Fig. 2) is a simple method for protein expression that employs DNA encoding a protein of interest and a synthesis reaction (cellular extract) mix, which contains amino acids and all essential biochemical components for gene transcription, translation, and protein production (including source of energy). Because it is independent of cell (e.g., E. coli) viability, the CFPS enables expression of proteins that are toxic for the cell substrate (Kapoor et al. 2018; Xu et al. 2015; Zawada et al. 2011). The absence of a cellular membrane creates an open system whereby components of the synthesis reaction can be manipulated to enhance transcription, translation, and folding. Unlike cell-based systems, only the gene of interest is transcribed and translated, which results in rapid and high yield protein production: typically, g/L yields in $8-10 \mathrm{~h}$. The process is scalable up to $>1000 \mathrm{~L}$ (Zawada et al. 2011), and protein can be manufactured under GMP at industry-level quantities within a few days. Using CFPS, both IpaB and IpaH-CTD were expressed at yields $>200 \mathrm{mg} / \mathrm{L}$ while the biophysical and antigenic characterization of the purified proteins indicated well-defined solution state structures harboring important conformational and immunologically relevant epitopes. The CFPS can therefore produce protein
Fig. 2 Schematic representation of the Xpress ${ }^{+\mathrm{TM}}$ CFPS technology. For CFPS, cellular extract from $E$. coli is harvested and added to a chemical mixture containing components (NTPs, amino acids, $\mathrm{Na}^{+} / \mathrm{K}^{+}$salts and cofactors) necessary for energy generation and transcription (through simultaneous addition of plasmid DNA encoding the target gene and $\mathrm{T} 7$ polymerase). Thereafter, the transcribed mRNA is readily utilized by the ribosomal translational machinery in the cellular extract to express the target protein in 8-10h.
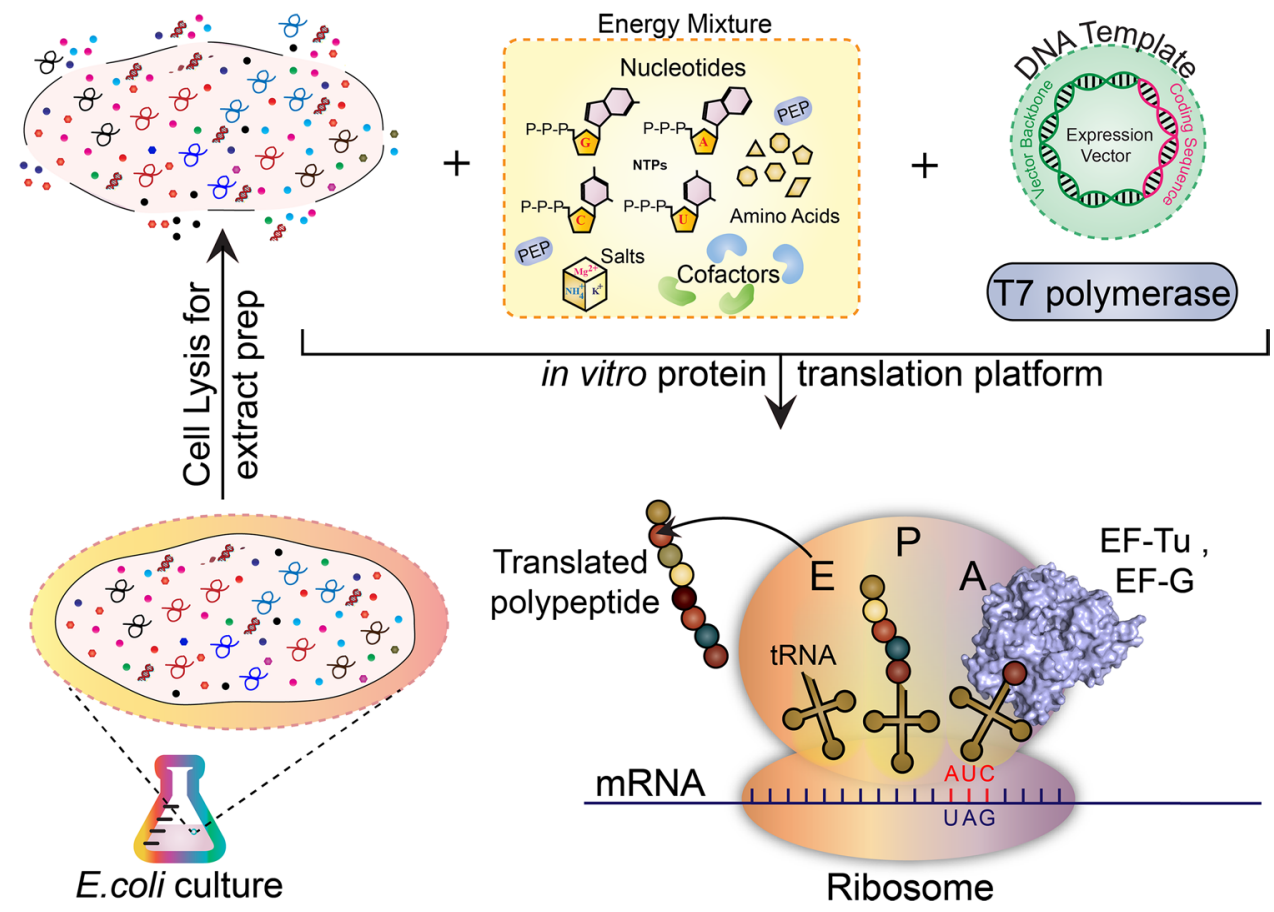
quantities compatible with industry manufacturing standards (Zawada et al. 2011) and thus facilitate the synthesis of these well-characterized antigens in a reliable and cost-effective manner for their evaluation as Shigella vaccine antigens or immune/diagnostic antigens.

\section{Materials and methods}

\section{Cloning, expression, and purification of IpgC, IpaB, and IpaH-CTD}

The genes for expression of IpgC (aa 1-155, GenBank \# AAP78992.1), IpaB (aa 1-580, GenBank \# SVH88885.1), and the C-terminal domain of IpaH1.4 (IpaH-CTD, aa 265-575, GenBank \# AAP79042.1) from S. flexneri 2a were synthesized at ATUM (Menlo Park, CA) and subcloned with an N-terminal methionine into a proprietary vector using NdeI and SalI as restriction sites. To facilitate protein capture and purification, IpaB was expressed with a C-terminal his ${ }_{6}$-tag, while full-length $\mathrm{IpgC}$ was expressed with a cleavable $\mathrm{N}$-terminal Twin Strep tag. To generate an untagged version of IpgC, the expression constructs harbored a TEV protease cleavage site $\mathrm{C}$-terminal to the affinity tag. For exogenous addition of untagged $\mathrm{IpgC}$ during synthesis, IpaB was expressed at large scale using a DASbox mini bioreactor system (Eppendorf, Enfield, CT) with $3 \mu \mathrm{g} / \mathrm{ml}$ of plasmid DNA added to the reaction. Expression was performed at $25^{\circ} \mathrm{C}$ for $10 \mathrm{~h}$ with constant stirring at $650 \mathrm{rpm}$ while maintaining the $\mathrm{pH}$ at 7.2 and sparging a blend of air and oxygen through the reaction mixture to maintain the dissolved oxygen at $30 \%$. After $10 \mathrm{~h}$, the reactions were harvested and spun down at $15,000 \mathrm{~g}$ at 4 ${ }^{\circ} \mathrm{C}$ for $30 \mathrm{~min}$ followed by filtration using a $0.45-\mu \mathrm{m}$ pore size membrane. For purification, the clarified filtrate with IpgC was loaded onto a $5 \mathrm{ml}$ StrepTactin XT column (IBA life sciences, Germany) equilibrated with Buffer A1 (50 mM Tris, 150 $\mathrm{mM} \mathrm{NaCl}$ ) followed by 30 column volumes (CVs) wash with Buffer A1 to bring the $\mathrm{A}_{280} \mathrm{~nm}$ absorbance back to baseline. The bound protein was eluted using Buffer A1 supplemented with $50 \mathrm{mM}$ biotin in a single step. The elution fractions were pooled and incubated with excess in-house purified his ${ }_{6}$-tagged TEV protease while dialyzing against Buffer A1. The next day, the dialyzed cleavage reaction was loaded back onto a pre-equilibrated HisTrap excel $5 \mathrm{ml}$ column (Cytiva, Sweden) followed by a StrepTactin XT column (IBA life sciences, Germany) to separate and purify the untagged IpgC away from the his ${ }_{6}$-tagged protease and the cleaved Twin Strep tag. Next, IpaB was expressed similarly in the CFPS in the presence of exogenously added $\mathrm{IpgC}(0.3 \mathrm{mg} / \mathrm{ml})$. For purification, postexpression clarified filtrate was loaded onto a $5 \mathrm{ml}$ HisTrap excel column pre-equilibrated with Buffer A2 $(50 \mathrm{mM}$ Tris, $150 \mathrm{mM} \mathrm{M} \mathrm{NaCl}, 10 \mathrm{mM}$ Imidazole, 0.1\% LDAO), which in turn also helped remove co-eluting IpgC from IpaB. Finally, the bound protein was eluted using a 50\% step gradient of Buffer A2 with $500 \mathrm{mM}$ imidazole. Post-capture, the elution fractions for IpaB were combined, concentrated using $30 \mathrm{kDa}$ cutoff Amicon ${ }^{\circledR}$ Ultra-15 centrifugal filters (Millipore Sigma, USA), and loaded onto a gel filtration Superdex200 26/60 column pre-equilibrated with Buffer S1 (50 mM Tris, $150 \mathrm{mM}$ $\mathrm{M} \mathrm{NaCl}, 0.1 \%$ LDAO). Fractions with the highest purity (> 95\% as assessed by SimplyBlue ${ }^{\mathrm{TM}}$ SafeStain (ThermoFisher, USA) staining post SDS-PAGE analysis were combined, aliquoted, and stored at $-80{ }^{\circ} \mathrm{C}$ for further use. The expression and purification for IpaH-CTD were performed similarly and post elution from HisTrap excel $5 \mathrm{ml}$ column using Buffer A3 (50 mM Tris, $150 \mathrm{mM} \mathrm{M} \mathrm{NaCl}, 10 \mathrm{mM}$ imidazole); the fractions were concentrated and loaded onto a Superdex75 26/60 column pre-equilibrated with Buffer S2 (50 mM Tris, $150 \mathrm{mM}$ $\mathrm{M} \mathrm{NaCl}$ ). The elution fractions were analyzed by SDS-PAGE analysis followed by SimplyBlue ${ }^{\mathrm{TM}}$ SafeStain safe blue staining. Fractions with the highest purity ( $>95 \%$ ) were combined, concentrated using $30 \mathrm{kDa}$ cutoff Amicon ${ }^{\circledR}$ Ultra-15 centrifugal filters (Millipore Sigma, USA), and aliquoted for storage at $-80{ }^{\circ} \mathrm{C}$. The concentration was measured by $\mathrm{A}_{280} \mathrm{~nm}$ while subtracting the background absorbance for the buffer alone.

\section{${ }^{14} \mathrm{C}$-leucine incorporation assay for estimate of protein expression}

The amount of total and soluble protein expressed using Xpress CFPS ${ }^{+\mathrm{TM}}$ platform was determined through ${ }^{14} \mathrm{C}$-leucine incorporation as described previously (Kapoor et al. 2018). ${ }^{14} \mathrm{C}$-leucine of $2 \mathrm{mM}$ (GE Life Sciences, Piscataway, $\mathrm{NJ}$ ) was added into the CFPS reaction mix and incorporated into the translating polypeptide at $25^{\circ} \mathrm{C}$. Post expression, reactions were harvested, and $4 \mu \mathrm{l}$ of either the complete CFPS reaction or the clarified supernatant (obtained after centrifuging the reaction at $4500 \mathrm{rpm}$ for $15 \mathrm{~min}$ at $25^{\circ} \mathrm{C}$ ) was blotted onto an anion exchange filter membrane. The membrane was extensively washed to remove unbound material and heat dried for $30 \mathrm{~min}$. Finally, the filter membrane was evenly coated with scintillation fluid, air-dried, and the counts recorded to estimate the total and soluble yield of the expressed proteins. Using these values, final titers were estimated using the formula:

Titer $=$ Recorded Counts $($ Total or Soluble post wash $) * \frac{\left(\frac{2 m M * \text { protein molecular mass }}{\# \text { Leucines }}\right)}{\text { Total Recorded Counts }}$ 


\section{Western blot analysis}

Post CFPS, reactions were spun down at $4500 \mathrm{rpm}$ to harvest the supernatant and pellet fractions. Thereafter, $10 \mu 1$ of supernatant and corresponding pellet were separately incubated with $4 \times$ LDS loading buffer heated at $75^{\circ} \mathrm{C}$ for 10 min followed by SDS-PAGE analysis using Nu-PAGE Bis-Tris $4-12 \%$ precast gels (Thermo Fisher Scientific, Waltham, MA). The size-separated proteins in the gel were then transferred onto a PVDF membrane using an iBlot apparatus (Thermo Fisher Scientific, Waltham, MA) following the manufacturer's protocol. After transfer, the membrane was blocked with $50 \mathrm{mM}$ Tris $\mathrm{pH} 8.0,50 \mathrm{mM}$ $\mathrm{NaCl}$, and 5\% BSA for 30 min followed by incubation with 1:10,000 diluted penta-his HRP monoclonal antibody (Qiagen, Hilden, Germany) for 30 min at RT with constant shaking. After incubation, the membrane was washed $3 \times$ with $50 \mathrm{mM}$ Tris $\mathrm{pH} 8.0,50 \mathrm{mM} \mathrm{NaCl}$, and 5\% BSA at RT for 30 min each. Finally, the membrane was dried and probed with super signal chemiluminescent pico substrate (ThermoFisher Cat\#34577) before imaging using Syngene G-Box F3 image scanner (Syngene, Frederick, MD).

\section{Multi-angle light scattering (MALS) analysis}

The SEC MALS-UV-RI setup consists of an Agilent HPLC 1100 degasser, temperature-controlled auto-sampler $\left(4^{\circ} \mathrm{C}\right)$, column compartment $\left(25^{\circ} \mathrm{C}\right)$, and UV-Vis diode array detector (Agilent, Santa Clara, CA) in line with a DAWN-HELEOS multi-angle laser light scattering detector and Optilab T-rEX differential refractive interferometer (Wyatt Technology, Santa Barbara, CA). The system was coupled to a Superdex200 10/30 Increase column for IpaB and Superdex75 10/30 GL for IpaH-CTD. A mobile phase consisting of $0.2 \mu \mathrm{m}$ filtered $50 \mathrm{mM}$ Tris $\mathrm{pH} 8,150 \mathrm{mM} \mathrm{NaCl}, 0.1 \%$ (v/v) LDAO for IpaB or just $50 \mathrm{mM}$ Tris $\mathrm{pH} 8$, and $150 \mathrm{mM} \mathrm{NaCl}$ for IpaH-CTD was used at a $0.5 \mathrm{~mL} / \mathrm{min}$ flow rate. Approximately $50-100-\mu \mathrm{g}$ sample was injected for analysis. Agilent Open Lab software was used to control the HPLC, and Wyatt Astra 7 software (Wyatt Technology Corp., Santa Barbara, CA) was used for data collection and molecular weight analysis.

\section{Clinical samples and analysis of IpaB and IpaH-CTD antibody reactivity}

Serum samples were obtained from two previous clinical studies performed on healthy community volunteers at the Center for Vaccine Development (University of Maryland, Baltimore) under IRB-approved protocols. The studies were:

(i) S.flexneri $2 a$ human challenge: Serum samples were obtained at days -1 (prior to challenge) and 28 (post challenge) from 14 volunteers who were fed $1 \times$
$10^{3} \mathrm{CFU}$ of the wild-type strain S.flexneri $2 a$ strain 2457T (ATCC \# 700930) as described previously (Kotloff et al. 1995). Specimens were selected from volunteers who remained healthy, as well as from those who experienced mild, moderate, and severe disease, as previously described (Shimanovich et al. 2017).

(ii) CVD 1204 vaccination: Serum samples were collected from 5 subjects orally immunized with a single dose of $1 \times 10^{9} \mathrm{CFU}$ of live attenuated S.flexneri $2 a$ vaccine strain CVD 1204 (produced at University of Maryland, Baltimore) (Noriega et al. 1996), which harbors deletion mutations in genes encoding enzymes in the guanine nucleotide synthesis pathway $(\triangle g u a B A)$, in a phase I clinical study (Kotloff et al. 2004). Serum samples collected at day -1 (prior to vaccination) and day 28 (post vaccination) were tested.

\section{Mouse immunizations}

Adult (6-8 weeks old) female BALB/c mice ( $n=10-20$ per group, Charles River Lab) were immunized intramuscularly on days 0,14 , and 28 with $10 \mu \mathrm{g}$ CFPS-purified IpaB or IpaH-CTD adsorbed to Adju-Phos® $(4.8 \% \mathrm{v} / \mathrm{v})$ in a 100 $\mu \mathrm{L}$ volume $(50 \mu \mathrm{L}$ per leg). Blood was collected at day -1 (one day prior to vaccination), and days 13, 27, 42, and 55 (post vaccination) for serum antibody measurement. Control groups received PBS or AdjuPhos®. Studies were approved by the University of Maryland Institutional Animal Care and Use Committee.

\section{Antibody measurements}

Antigen-specific serum IgG titers specific for IpaB and IpaHCTD were measured by ELISA as previously described (Martinez-Becerra et al. 2012; Shimanovich et al. 2017). Briefly, Immulon 2HB plates (Thermo Scientific, Waltham, MA) were coated with IpaB or IpaH-CTD at $0.1 \mu \mathrm{g} / \mathrm{mL}$ in PBS. Plates were incubated for $3 \mathrm{~h}$ at $37^{\circ} \mathrm{C}$ and blocked at $4{ }^{\circ} \mathrm{C}$ overnight in PBS containing $10 \%$ non-fat dry milk (NFDM). Sera serially diluted in PBS containing 10\% NFDM and $0.05 \%$ Tween-20 (PBS-T) were added, and the plates incubated at $37^{\circ} \mathrm{C}$ for $1 \mathrm{~h}$. Plates were incubated with HRPlabeled goat IgG specific for human or mouse IgG (Jackson Immuno Research, West Grove, PA) for another $1 \mathrm{~h}$ at 37 ${ }^{\circ} \mathrm{C}$. Plates were washed 6 times with PBS-T following every incubation step. Tetramethylbenzidine (TMB; KPL, Gaithersburg, MD) was added as substrate for $15 \mathrm{~min}$ in the dark with shaking, and the reaction was stopped by adding 100 $\mu 1 \mathrm{M}$ phosphoric acid (Millipore Sigma, Burlington, MA). Plates were read using an Multiskan Accent ${ }^{\mathrm{TM}}$ Microplate Reader (Thermo Scientific, Waltham, MA). Endpoint titers 
were calculated by interpolation of absorbance values of samples in the regression curve of a positive control and were reported as ELISA units/mL corresponding to the inverse serum dilution resulting in an $\mathrm{A}_{450}$ of 0.2 above background.

\section{Statistical analysis}

Antibody titers were analyzed by paired $t$-test. Differences were considered statistically significant at $p<0.05$. All statistical analysis was conducted using GraphPad Prism 9 (GraphPad Software, La Jolla, CA).

\section{Results}

\section{Exogenous addition of IpgC to CFPS enhances expression, solubility, and recovery yields of IpaB}

Structurally, Shigella IpaB has a modular architecture that includes the cytosolic chaperone IpgC binding domain (aa 15-72) (Ferrari et al. 2021; Lokareddy et al.
2010), a coiled-coil region (aa 74-239 or $110-170$ or 85-200) (Ferrari et al. 2021; Oaks and Turbyfill 1992), a central hydrophobic domain, and a putative protein binding region towards the $\mathrm{C}$-terminal end of the protein (Fig. 3a) (Guichon et al. 2001; Shen et al. 2010). IpaB has traditionally been purified using cell-based expression platforms (i.e., E. coli) (Barta et al. 2017; Hume et al. 2003; Martinez-Becerra et al. 2012). This method was used to produce modest quantities of IpaB with acceptable purity for biophysical and functional analyses (Barta et al. 2018), as well as preclinical studies on this potential vaccine candidate (Chitradevi et al. 2016; Heine et al. 2013; Martinez-Becerra et al. 2012). We have adapted and optimized the cell-free Xpress ${ }^{+\mathrm{TM}}$ CFPS to produce large quantities of pure, soluble IpaB for immunological and vaccine studies. Expression of IpaB alone at room temperature resulted in $>200 \mathrm{mg} / \mathrm{L}$ of soluble protein, as estimated through ${ }^{14} \mathrm{C}$-leucine incorporation into the translating polypeptide (Fig. 3b). However, SEC-MALS analysis revealed aggregated protein (data not shown). IpaB is kept in its native non-aggregated
Fig. 3 Expression, purification, and biophysical characterization of IpaB. a Modular architecture of IpaB indicating IpgC binding domains near the $\mathrm{N}$-terminus. IpaB co-expressed with IpgC in CFPS reaction containing increasing amounts of IpgC pDNA (b) and IpaB expressed alone when increasing amounts of purified $\mathrm{IpgC}$ were added to the CFPS reaction (c); protein amount was determined using ${ }^{14} \mathrm{C}$-leucine incorporation and data represent mean protein concentration \pm SD from 3 independent measurements. d Western blot analysis of the supernatant and pellet fractions from co-expression of IpaB with increasing amounts of purified $\mathrm{IpgC}$ in scaled up thin-layer reactions shows complete recovery of IpaB into the soluble fraction when $>30 \mu \mathrm{g}$ of IpgC was added. e SDS-PAGE analysis shows significantly higher amounts of IpaB recovered in the elution fractions when purified IpgC was exogenously added into the reaction mixture (f) SECMALS analysis of purified IpaB (inset, $>95 \%$ purity as assessed by SDS-PAGE analysis) shows primarily dimeric state of the protein in solution.

(a)

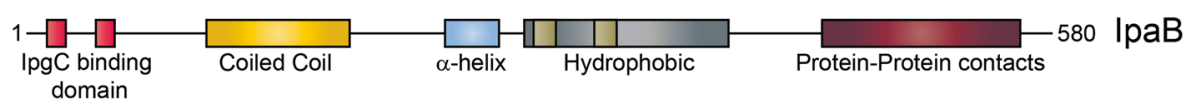

(b)

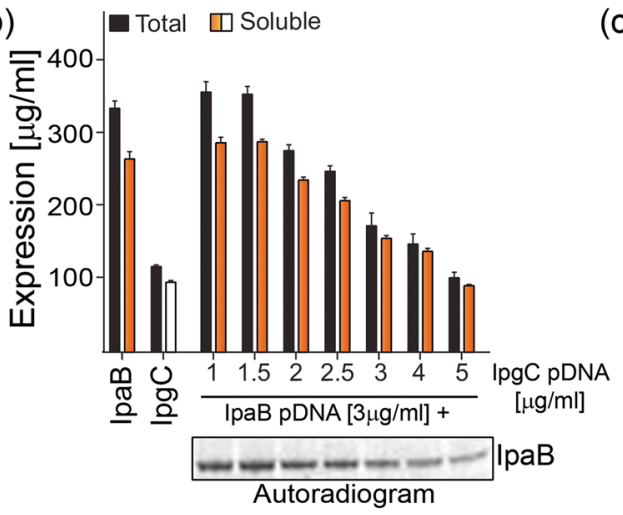

(c)

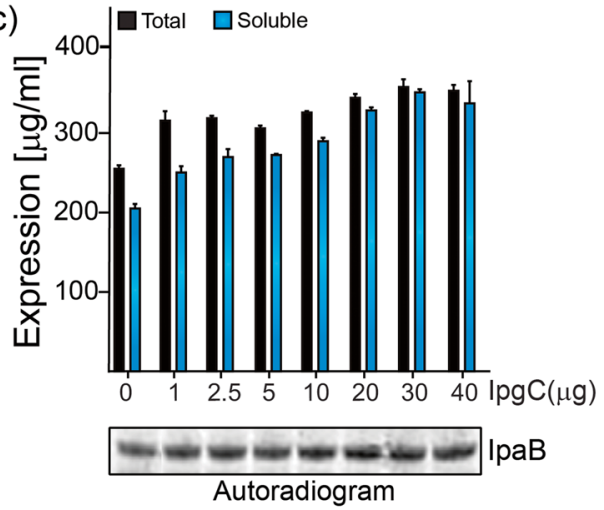

(d)

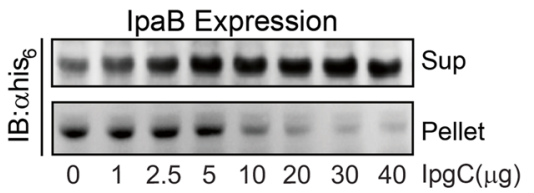

(e)

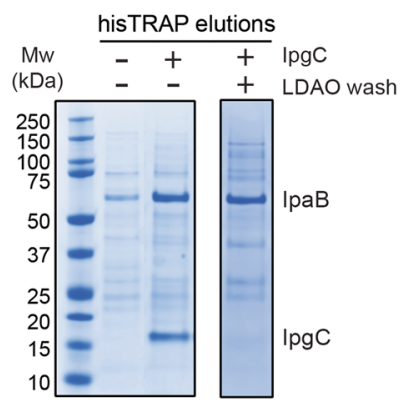

(f)

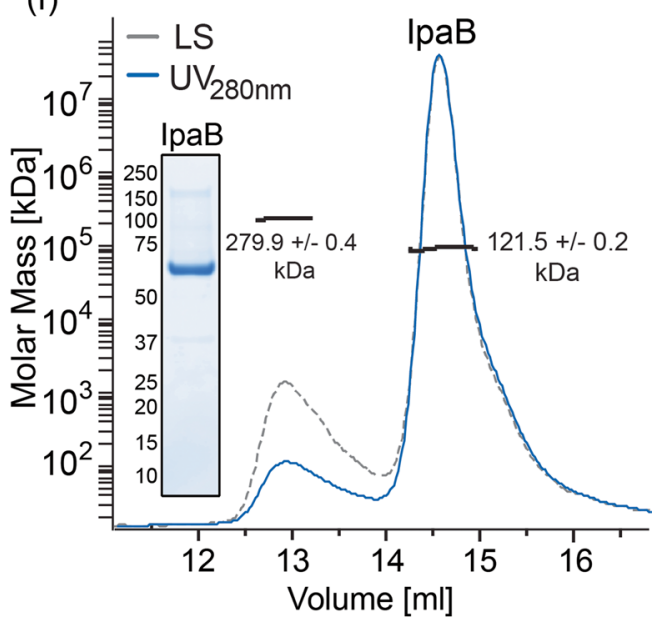


form in the bacterial cytosol through interaction with its cognate molecular chaperone, IpgC (Ménard et al. 1994; Picking et al. 1996; Picking and Picking 2016). IpaB binding to IpgC also prevents degradation; thus, co-expression of IpaB with $\mathrm{IpgC}$ in E. coli enabled viable purification of IpaB (Birket et al. 2007; Lokareddy et al. 2010). Building on these observations, we utilized the open nature of the CFPS to co-express full-length IpaB while adding to the reaction mix increasing amounts of IpgC-encoding plasmid DNA (pDNA) using a 96-well plate reaction format. The incremental addition of ipgC expression pDNA dramatically lowered the expression of IpaB (Fig. 3b), possibly due to dominant expression of IpgC itself at higher pDNA concentrations. To circumvent this limitation, we examined IpaB expression with increasing amounts of purified $\mathrm{IpgC}$ protein (up to $40 \mu$ g, i.e., $28 \mu \mathrm{M}$ ) instead of ipgC expression pDNA added to the reaction mix. The addition of $\mathrm{IpgC}$ into the cell-free media improved both the total and soluble IpaB yields, reaching saturation at $>30 \mu \mathrm{g}(\sim 21 \mu \mathrm{M})$ of IpgC (Fig. 3c). Using these conditions, we next investigated the effect of $\mathrm{IpgC}$ on IpaB aggregation and precipitation. Exogenous addition of purified $\operatorname{IpgC}$ (up to $30 \mu \mathrm{g}$ ) eliminated IpaB precipitation and allowed for complete solubilization of IpaB, as shown by Western Blot analysis (Fig. 3d). Finally, we scaled up expression of IpaB to $1 \mathrm{~L}$ alone or with $\mathrm{IpgC}$ at $25^{\circ} \mathrm{C}$ and $\mathrm{pH} 7.2$ using a DASbox bioreactor. His $_{6}$-tagged IpaB was captured from the clarified reaction mix supernatant. SDS-PAGE analysis revealed higher amounts of IpaB in the elution fractions when purified IpgC was added to the CFPS reaction (Fig. 3e). Importantly, the co-eluting chaperone was effectively removed from IpaB, by washing the column bound protein fraction with loading buffer supplemented with the zwitterionic detergent lauryl diamine oxide (LDAO). Thereafter, the consolidated HisTrap elution fractions were subjected to size exclusion chromatography using a pre-equilibrated Superdex200 26/60 column and the elution fractions were analyzed by SDS-PAGE. Highest purity (>95\%) IpaB-containing fractions were combined, concentrated, aliquoted, and stored at $-80^{\circ} \mathrm{C}$. Finally, SEC-MALS analysis performed on purified IpaB showed that the CFPS-produced IpaB had a molecular mass of $121.5 \pm 0.2 \mathrm{kDa}$, which is a close approximation to the theoretical mass of $124.2 \mathrm{kDa}$ for an IpaB dimer.

\section{Expression, purification, and biophysical characterization of cell-free generated IpaH-CTD}

Similar to IpaB, the IpaH family of virulence proteins (encoded on both the chromosome and virulence plasmid) are secreted through the T3SS. Structurally, all members
Fig. 4 Expression, purification, and characterization of IpaH-CTD generated using CFPS platform. a Schematic representation of full length IpaH1.4 illustrating the leucine repeat-rich N-terminal (NTD) protein-protein interaction domain followed by the highly conserved C-terminal catalytic domain (CTD) with E3 ligase activity. b Using ${ }^{14} \mathrm{C}$-leucine incorporation, expression yield of IpaH-CTD was estimated > $300 \mu \mathrm{g} / \mathrm{ml}$ with a single band corresponding to IpaH-CTD in the autoradiogram. Bars represent mean protein concentration \pm SD from 3 independent measurements. c SDS-PAGE analysis of the purified protein followed by SimplyBlue ${ }^{\mathrm{TM}}$ SafeStain staining shows a single band with purity $>95 \%$. d SEC-MALS analysis of purified IpaH-CTD shows monomeric state in solution

(a)

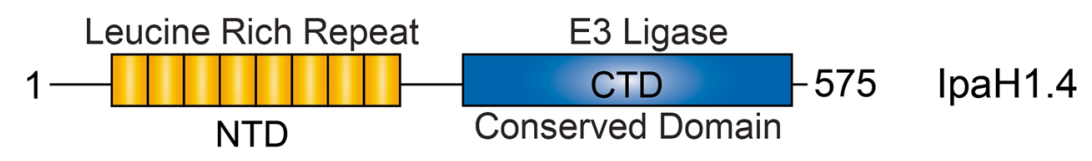

(b)

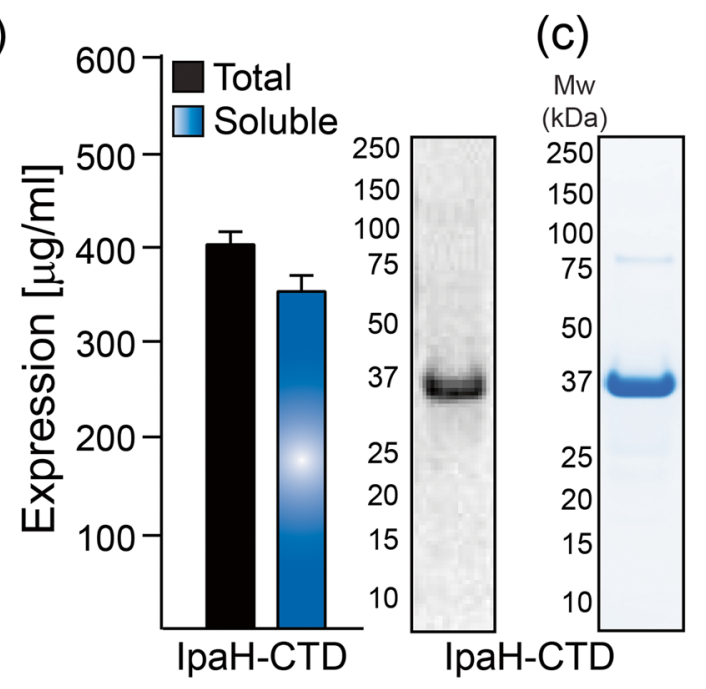

(d) -575 IpaH-CTD

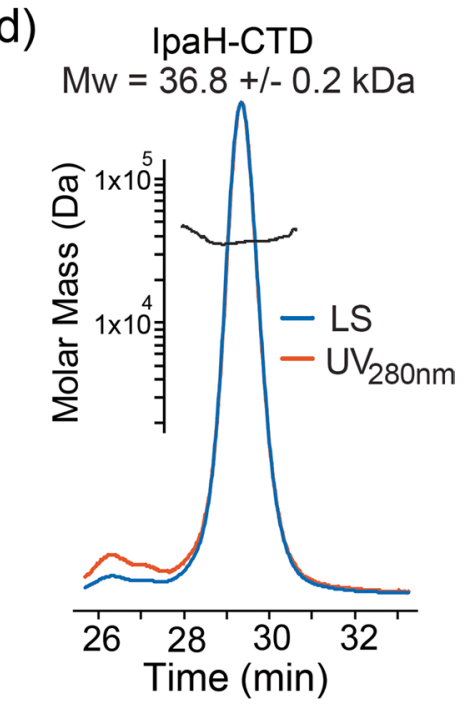


harbor an N-terminal leucine-rich repeat region domain (NTD) followed by a C-terminal catalytic core domain (CTD) that possesses E3 ligase activity (Ashida et al. 2007) (Fig. 4a). IpaH has been primarily a gene/antigen used for diagnostic purposes (Lindsay et al. 2013; Liu et al. 2016; Sahl et al. 2015). While the $\mathrm{N}$-terminal domain varies among the 9 IpaH proteins, the C-terminal domain is conserved between all isoforms (Ashida and Sasakawa 2015). As described for IpaB, we adapted and optimized the CFPS platform to express and purify large amounts of the IpaH1.4 C-terminal domain (IpaH-CTD). IpaH1.4 was one of the top isoforms recognized by serum from vaccinated or S.flexneri $2 a$-challenged individuals using a core Shigella proteome microarray (Ndungo et al. 2018). Using ${ }^{14} \mathrm{C}$-leucine incorporation, the total and soluble IpaH-CTD was estimated to be $>$ $300 \mathrm{mg} / \mathrm{L}$ (Fig. 4b). SDS-PAGE analysis of the CFPS reactions revealed a single protein fragment in the autoradiogram (Fig. 4b). Thereafter, expression of $\mathrm{N}$-terminally his ${ }_{6}$-tagged IpaH-CTD was scaled up at $25^{\circ} \mathrm{C}$ and $\mathrm{pH} 7.2$ in a DASbox bioreactor. Post-expression his ${ }_{6}$-tagged IpaH-CTD was captured from the clarified supernatant using HisTrap column chromatography. Thereafter, the elution fractions were combined, concentrated, and subjected to size exclusion chromatography using a Superdex 75 16/60 column. The elution fractions were analyzed by SDS-PAGE followed by safe-blue staining (Fig. 4c). The highest purity fractions (> 95\%) were combined and concentrated, aliquoted, and stored at $-80{ }^{\circ} \mathrm{C}$. The recovery yields of IpaH-CTD were estimated to be $\sim 200 \mathrm{mg} / \mathrm{L}$ using $\mathrm{A}_{280}$ absorbance. The insolution biophysical state of the purified IpaH-CTD (Fig. 4d) was investigated by SEC-MALS analysis, which estimated a molecular mass of $36.8 \pm 0.2 \mathrm{kDa}$; this value is in close agreement with the theoretical molecular mass of $36.4 \mathrm{kDa}$ for an IpaH-CTD monomer.

\section{Immune reactivity of Shigella IpaB and IpaH-CTD produced in the CFPS}

To determine the immune reactivity of CFPS-purified IpaB and IpaH-CTD, we evaluated their recognition by serum antibodies from individuals challenged with WT S.flexneri $2 a$ (Kotloff et al. 1995) or orally immunized with a liveattenuated S.flexneri $2 a$ vaccine (CVD 1204) (Kotloff et al. 2004). IpaB antibody binding was determined by ELISA using IpaB produced in E. coli; this method had been used by our group and others (Frenck Jr. et al. 2018; Shimanovich et al. 2017). Serum antibody titers measured against IpaB produced in E. coli and CFPS were compared and found to be almost identical in absolute numbers and strongly correlated (Fig. 5a). These results demonstrate that immune reactive epitopes are maintained in the CFPS-purified IpaB and that the absolute antibody content detected was similar regardless of the purification method. Immune responses to (a)

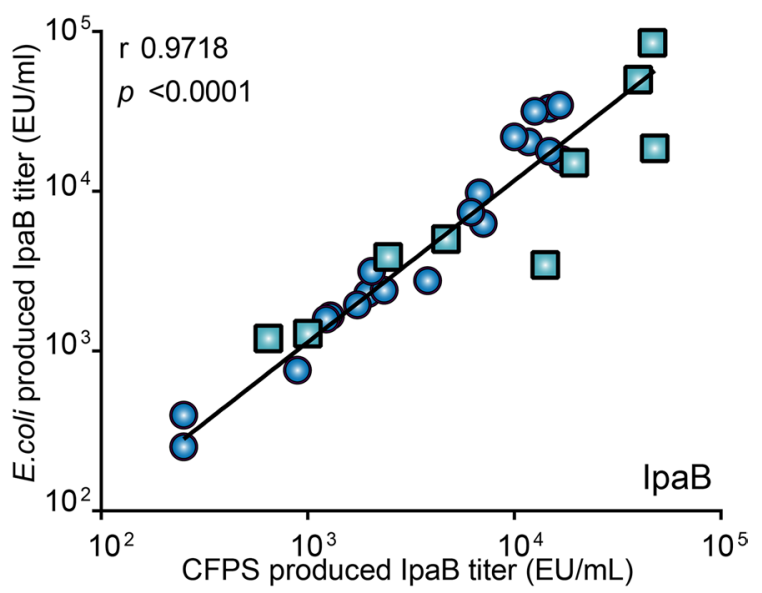

(b)

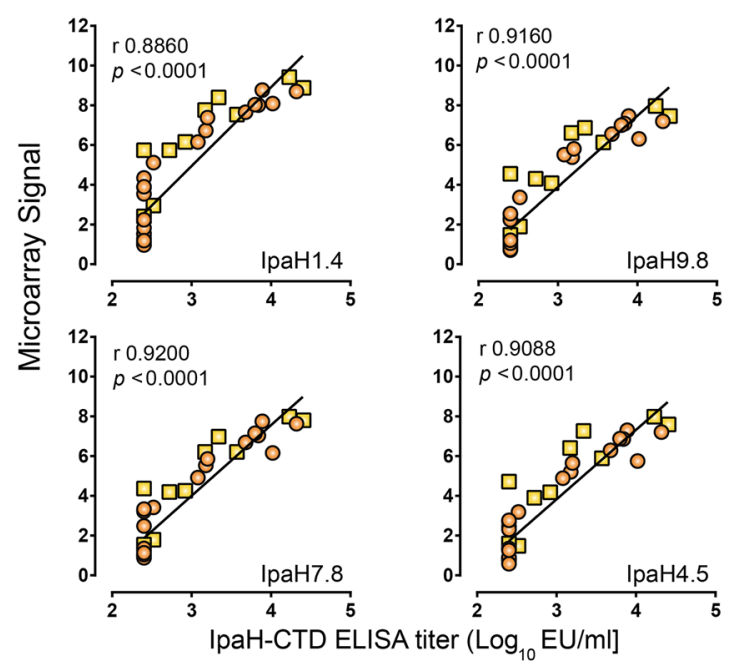

Fig. 5 Immune reactivity of IpaB and IpaH-CTD produced in CFPS. Serum IgG titers against IpaB (a) or IpaH-CTD (b) in 14 volunteers pre- and post-challenge with S.flexneri $2 a$ (circles) and 5 volunteers pre- and post-immunization with live-attenuated S.flexneri $2 a$ (squares) measured by ELISA using IpaB or IpaH-CTD produced in CFPS versus titers obtained by ELISA using IpaB produced in $E$. coli (a) or versus IpaH-specific antibody binding signals obtained in a protein microarray (b). Pearson correlation coefficient (r) and $p$ value are indicated

IpaH have not been previously evaluated in Shigella clinical studies as sufficient purified (and well-characterized) IpaH was not available. To evaluate immunoreactivity of CFPS IpaH-CTD, antibody titers obtained using this protein as coating antigen in an ELISA (similar to that described above for IpaB) were compared to normalized antibody binding signals against full-length IpaH1.4 that were obtained using the microarray platform previously described (Ndungo et al. 2018). A strong correlation was found between the ELISA titers and the microarray signal intensities as shown in Fig. 5b. Interestingly, IpaH-CTD ELISA titers were also correlated with the normalized signal intensities to three other IpaH isoforms on the microarray (Fig. 5b). These 
results confirm the antigenicity of IpaH-CTD and show that antibodies directed to the conserved C-terminal domain can target multiple IpaH isoforms. IpaH produced in E. coli was not available for side-by-side antibody titer comparison.

\section{Immunogenicity of CFPS-produced IpaB and IpaH-CTD in mice}

We had previously shown that IpaB is a strong immunogen in mice immunized via the oral, intranasal, and intradermal routes (Heine et al. 2014; Heine et al. 2013; MartinezBecerra et al. 2012). Here, we further demonstrated that IpaB and IpaH-CTD admixed with Adju-Phos ${ }^{\circledR}$ and administered intramuscularly to adult BALB/c mice were well tolerated and generated strong serum antibody responses (Fig. 6a and b). Antibody titers to both proteins improved after each subsequent vaccination. IpaB-specific titers continued to increase even 4 weeks after the third vaccine dose (the last time point measured) while antibody titers specific to IpaH-CTD remain unchanged between days 42 and 55 (Fig. 6a and b). These results confirm the in vivo immunogenicity of both proteins and the immunodominant properties of IpaB.

\section{Discussion}

A safe, effective, simple to manufacture, and affordable Shigella vaccine that can reduce moderate to severe diarrhea in young children in low- and middle-income countries can have a major public health impact. Travelers and military personnel deployed to endemic regions could also benefit from such a vaccine. Clinically advanced vaccine candidates rely on generating immunity against the bacterial $\mathrm{O}$-antigen (Cohen et al. 2021; Riddle et al. 2011; Walker et al. 2021). A major limitation of this approach is restricted coverage and at least a quadrivalent formulation would be needed to afford immunity against $60-70 \%$ of the most prevalent circulating Shigella strains (Livio et al. 2014; Noriega et al. 1999). The need for a multivalent vaccine also complicates clinical evaluation and increases cost of vaccine manufacturing. Most importantly, the effectiveness of such a vaccine in young children, who failed to develop protective levels of Shigella LPS antibodies in response to an early administration of a protein-conjugate vaccine (Passwell et al. 2010), remains to be demonstrated.

Similar to other enteric pathogens, Shigella has a T3SS apparatus that enables translocation of virulence factors required for bacterial infection of the human colonic epithelium. T3SS proteins, primarily IpaB, IpaC, and IpaD, are known to stimulate a robust host immune response after infection and have been identified as potential Shigella (a)

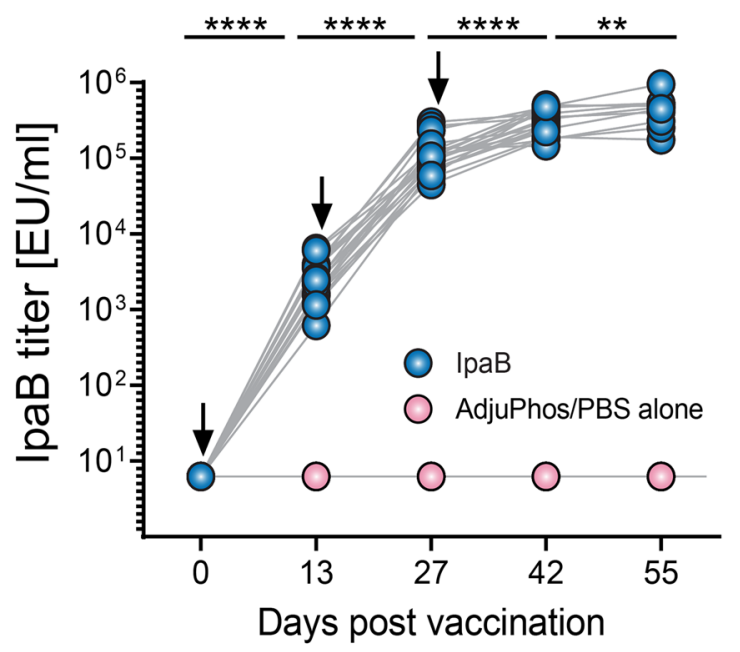

(b)

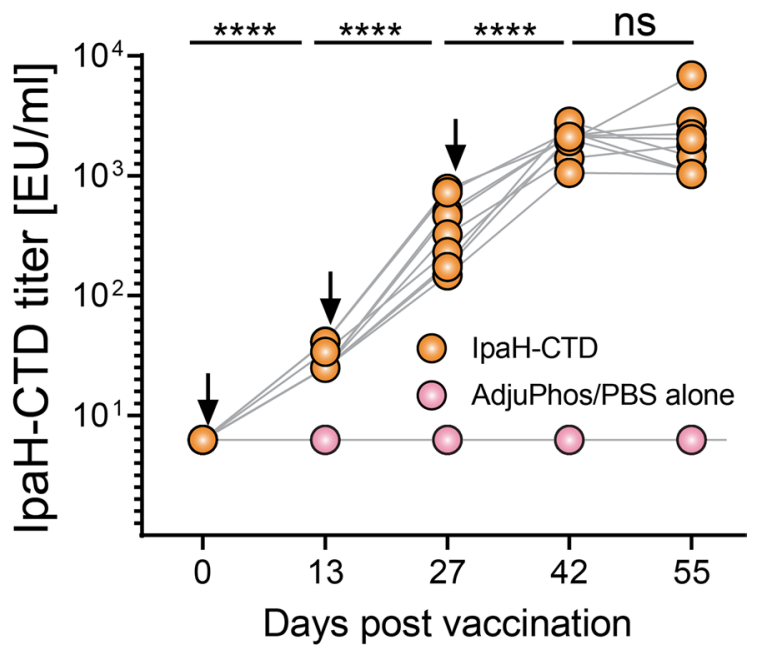

Fig. 6 Immunogenicity of Shigella IpaB and IpaH produced in the CFPS. Adult female BALB/c mice (10-20/group) were immunized intramuscularly on days 0,14 , and 28 (arrows) with $10 \mu \mathrm{g}$ of CFPSproduced IpaB (a) and IpaH-CTD (b) adjuvanted with Adju-Phos. Serum IgG titers were measured on days $-1,13,27,42$, and 55. Data represent titers in each individual animal. Titers over time were compared by paired- $t$ test analysis. Not significant (ns), $p<0.005(* *)$, $p<0.0001(* * * *)$

vaccine targets (Chitradevi et al. 2016; Martinez-Becerra et al. 2012; Turbyfill et al. 2018). Because the Ipa proteins are highly conserved among Shigella species, a vaccine based on Ipa proteins would afford broad coverage. A protein-only vaccine would be easier to consistently manufacture and more economical than an $\mathrm{O}$-antigen based multicomponent vaccine. There is precedent of successful routine immunization of children with parenterally delivered protein-based vaccines to protect communities (Anderson et al. 2018; Briere et al. 2014; Guris et al. 1997; Turbyfill et al. 2018). The clinical advancement of a Shigella protein vaccine would require an efficient and 
scalable production method in place. The CFPS system described herein represents a novel GMP-compatible platform technology for large-scale production of IpaB and IpaH-CTD that overcomes the yield limitations of cellbased methods.

IpaB is highly immunogenic and a putative protective antigen. IpaB-specific serum IgG has been associated with clinical protection in experimentally challenged individuals, (Shimanovich et al. 2017), and multiple studies have reported the protective capacity of IpaB in mice (Chitradevi et al. 2016; Heine et al. 2014; Heine et al. 2013; Heine et al. 2015; Martinez-Becerra et al. 2012). Yet, IpaB has never been tested as a vaccine candidate in humans. The evaluation of vaccines in clinical studies requires large quantities of a highly pure and well-characterized investigational product with an acceptable stability profile. Similarly, high-quality antigens are needed for immunological analysis. Researchgrade IpaB produced in E. coli used for research purposes did not meet requirements for clinical evaluation. An attempt to produce a Shigella IpaB-D fusion (Martinez-Becerra et al. 2013a) for a human phase 1 study failed at the manufacturing stage, and the clinical development program (supported by PATH) was halted (Wilbur Chen, personal communication). The CFPS platform reported here allowed for scaledup production of highly pure and soluble IpaB. The CFPSIpaB performed similarly to $E$. coli-derived IpaB when used as coating antigen in a traditional indirect ELISA. The CFPS-IpaB administered to mice intramuscularly adjuvanted with alum was immunogenic and elicited a robust serum IgG response, even after a single vaccination. Thus, our results indicate that not only is IpaB produced by CFPS comparable to $E$. coli-produced IpaB, but it can also be efficiently produced at high yields $(>200 \mathrm{mg} / \mathrm{L})$ greatly exceeding the low milligram IpaB yields reported in the literature using conventional cell-based methods (Picking et al. 1996).

The ipa $\mathrm{H}$ gene family has been successfully utilized as a molecular diagnostic marker, but unlike IpaB, the immunogenicity of IpaH has not been studied. We have reported that IpaH was recognized by circulating antibodies from orally vaccinated or S.flexneri $2 a$-challenged individuals (Ndungo et al. 2018). Herein, we showed that the CFPS generated IpaH-CTD was also similarly recognized by antibodies from Shigella-exposed subjects, which demonstrates that IpaHCTD maintained immunoreactive epitopes. Antibody reactivity to the conserved C-terminal domain was associated with signals from multiple IpaH isoforms, confirming the conserved nature of the purified protein. In addition, purified IpaH-CTD elicited strong serum IgG immune responses in mice, confirming its immunogenicity. Availability of the IpaH-CTD in large quantities would allow investigations on its structure and its potential use as an immunodiagnostic tool and vaccine candidate. The conserved nature of the C-terminal domain suggests that the purified protein could be helpful in facilitating further studies of members of the IpaH family of proteins.

The CFPS platform is being implemented for production of additional Ipas (i.e., IpaA, IpaC, and IpaD). Access to large quantities of highly pure Shigella T3SS proteins offers the opportunity for biophysical and functional studies to better understand the mechanisms by which these proteins interact with other bacterial and host elements. High-resolution structural information and details on precise immunological priming and effector mechanisms of these proteins, particularly in relation to protective immunity, can help guide the design of safe and effective vaccines. The CFPS approach can also be extended to obtain T3SS proteins from other pathogens.

A variety of proteins from growth factors, toxins, and viral-like particles (Chiba et al. 2021; Gao et al. 2021; Zawada et al. 2011; Zichel et al. 2010) have been produced successfully using CFPS. In addition, complex antibody drug conjugates have been generated using the CFPS and linearly scaled from research to GMP manufacturing levels for evaluation in clinical trials (Abrahams et al. 2018). The open nature of the platform incentivizes real-time sampling and manipulation of the reaction conditions to optimize protein expression and solubility. Unlike cell-based systems, the absence of membranous architecture permits configurational flexibility by allowing addition of surfactants/lipids and biochemical components to influence $\mathrm{pH}$ and oxidative potential and improve solubility of protein targets that would otherwise be hard to generate (Jewett and Swartz 2004; Kapoor et al. 2018; Kim and Swartz 2004). Furthermore, unlike cell-based systems, which require cloning and transformation of cells to initiate antigen production, CFPS reduces the process completion time from weeks to hours, as the synthesized gene once cloned into the expression vector can be immediately utilized to initiate protein expression. Importantly, the lack of post-translational modification machinery also promotes generation of molecularly consistent proteins that are easier to biophysically characterize at scale (Yin et al. 2012). Finally, initiation of protein purification does not require time-consuming steps like cell lysis, as the harvested cell-free reaction can just be centrifuged or depth filter clarified for immediate loading onto a capture column for protein purification. These major process improvements result in significant cost reductions for production of affordable vaccine targets (Chiba et al. 2021; Sheng et al. 2017; Zichel et al. 2010). Using CFPS, Sheng et al. (Sheng et al. 2017) estimated that generation time of norovirus viral-like particle vaccine was $>40 \mathrm{~h}$ less, compared to cell-based systems, while the cost/dose was still within the \$2.5-5.0/dose range of cell-based systems. Such improvements in process efficiencies can provide significant cost savings for GMP production of a Shigella vaccine, which will primarily be deployed (and most needed) in resource-poor regions across the world. In summary, CFPS is a scalable, simple, fast, 
practical, and robust GMP-compatible platform for efficient synthesis of biological products. The CFPS technology opens the way for efficient scale-up of production of well characterized Shigella vaccine targets like IpaB and IpaH for research studies and to support phase 1 clinical trials.

Acknowledgments We thank Fr. Marin Mersenne for his assistance and Joel Marx for IpaB vaccination experiments.

Author contribution NK, EN, LP, MP, and JF conceived and designed the research. NK and LP were responsible for conducting expression and purification of IpaB and IpaH-CTD, while AB performed the SECMALS analysis. EN and GD performed immunization and in vitro titer analysis for the antigens. NK, EN, GD, MP, and EO wrote the manuscript. All authors read and approved the manuscript.

Funding This work was financially supported by National Institutes of Health (NIH) award: 1R01 AI161839-01.

Availability of data and material The datasets generated and/or analyzed during the current study are available from the corresponding authors on reasonable request.

\section{Declarations}

Ethics approval The use of anonymized, stored, serum samples used in these studies was reviewed by the University of Maryland School of Medicine IRB and determined to constitute NHSR under IRB HP-00069144.

\section{Consent to participate Not applicable.}

Consent for publication All authors consent that this study is to be submitted for publication.

Conflict of interest The authors declare no competing interests.

Open Access This article is licensed under a Creative Commons Attribution 4.0 International License, which permits use, sharing, adaptation, distribution and reproduction in any medium or format, as long as you give appropriate credit to the original author(s) and the source, provide a link to the Creative Commons licence, and indicate if changes were made. The images or other third party material in this article are included in the article's Creative Commons licence, unless indicated otherwise in a credit line to the material. If material is not included in the article's Creative Commons licence and your intended use is not permitted by statutory regulation or exceeds the permitted use, you will need to obtain permission directly from the copyright holder. To view a copy of this licence, visit http://creativecommons.org/licenses/by/4.0/.

\section{References}

Abrahams CL, Li X, Embry M, Yu A, Krimm S, Krueger S, Greenland NY, Wen KW, Jones C, DeAlmeida V, Solis WA, Matheny S, Kline T, Yam AY, Stafford R, Wiita AP, Hallam T, Lupher M, Molina A (2018) Targeting CD74 in multiple myeloma with the novel, site-specific antibody-drug conjugate STRO-001. Oncotarget 9(102):37700-37714. https://doi.org/10.18632/oncotarget. 26491
Anderson EJ, Daugherty MA, Pickering LK, Orenstein WA, Yogev $\mathrm{R}$ (2018) Protecting the community through child caccination. Clin Infect Dis 67(3):464-471. https://doi.org/10.1093/cid/ciy142

Ashida H, Sasakawa C (2015) Shigella IpaH family effectors as a versatile model for studying pathogenic bacteria. Front Cell Infect Microbiol 5:100. https://doi.org/10.3389/fcimb.2015.00100

Ashida H, Toyotome T, Nagai T, Sasakawa C (2007) Shigella chromosomal IpaH proteins are secreted via the type III secretion system and act as effectors. Mol Microbiol 63(3):680-693. https://doi. org/10.1111/j.1365-2958.2006.05547.x

Avci F, Berti F, Dull P, Hennessey J, Pavliak V, Prasad AK, Vann W, Wacker M, Marcq O (2019) Glycoconjugates: what it would take to master these well-known yet little-understood immunogens for vaccine development. mSphere 4(5):e00520-e00519. https://doi. org/10.1128/mSphere.00520-19

Bajunaid W, Haidar-Ahmad N, Kottarampatel AH, Ourida Manigat F, Silué N, Tchagang CF, Tomaro K, Campbell-Valois FX (2020) The T3SS of Shigella: expression, structure, function, and role in vacuole escape. Microorganisms 8(12):1933. https://doi.org/10. 3390/microorganisms 8121933

Barta ML, Adam PR, Dickenson NE (2017) Recombinant expression and purification of the Shigella translocator IpaB. Methods Mol Biol 1531:173-181. https://doi.org/10.1007/978-1-4939-6649-3_ 15

Barta ML, Tachiyama S, Muthuramalingam M, Arizmendi O, Villanueva CE, Ramyar KX, Geisbrecht BV, Lovell S, Battaile KP, Picking WL, Picking WD (2018) Using disruptive insertional mutagenesis to identify the in situ structure-function landscape of the Shigella translocator protein IpaB. Protein Sci 27(8):13921406. https://doi.org/10.1002/pro.3428

Birket SE, Harrington AT, Espina M, Smith ND, Terry CM, Darboe N, Markham AP, Middaugh CR, Picking WL, Picking WD (2007) Preparation and characterization of translocator/chaperone complexes and their component proteins from Shigella flexneri. Biochemistry 46(27):8128-8137. https://doi.org/10.1021/bi700099c

Briere EC, Rubin L, Moro PL, Cohn A, Clark T, Messonnier N (2014) Prevention and control of haemophilus influenzae type $b$ disease: recommendations of the advisory committee on immunization practices (ACIP). MMWR Recomm Rep 63(Rr-01):1-14

Chiba CH, Knirsch MC, Azzoni AR, Moreira AR, Stephano MA (2021) Cell-free protein synthesis: advances on production process for biopharmaceuticals and immunobiological products. Biotechniques 70(2):126-133. https://doi.org/10.2144/btn-2020-0155

Chitradevi ST, Kaur G, Uppalapati S, Yadav A, Singh D, Bansal A (2015) Co-administration of rIpaB domain of Shigella with rGroEL of S. Typhi enhances the immune responses and protective efficacy against Shigella infection. Cell Mol Immunol 12(6):757-767. https://doi.org/10.1038/cmi.2014.86

Chitradevi STS, Kaur G, Sivaramakrishna U, Singh D, Bansal A (2016) Development of recombinant vaccine candidate molecule against Shigella infection. Vaccine 34(44):5376-5383. https://doi.org/10. 1016/j.vaccine.2016.08.034

Cohen D, Atsmon J, Artaud C, Meron-Sudai S, Gougeon ML, Bialik A, Goren S, Asato V, Ariel-Cohen O, Reizis A, Dorman A, Hoitink CWG, Westdijk J, Ashkenazi S, Sansonetti P, Mulard LA, Phalipon A (2021) Safety and immunogenicity of a synthetic carbohydrate conjugate vaccine against Shigella flexneri $2 a$ in healthy adult volunteers: a phase 1 , dose-escalating, singleblind, randomised, placebo-controlled study. Lancet Infect Dis 21(4):546-558. https://doi.org/10.1016/s1473-3099(20)30488-6

Cohen D, Green MS, Block C, Slepon R, Ofek I (1991) Prospective study of the association between serum antibodies to lipopolysaccharide $\mathrm{O}$ antigen and the attack rate of shigellosis. J Clin Microbiol 29(2):386-389. https://doi.org/10.1128/jcm.29.2.386389.1991 
Cohen D, Meron-Sudai S, Bialik A, Asato V, Goren S, Ariel-Cohen O, Reizis A, Hochberg A, Ashkenazi S (2019) Serum IgG antibodies to Shigella lipopolysaccharide antigens - a correlate of protection against shigellosis. Hum Vaccin Immunother 15(6):1401-1408. https://doi.org/10.1080/21645515.2019.1606971

Dickenson NE, Choudhari SP, Adam PR, Kramer RM, Joshi SB, Middaugh CR, Picking WL, Picking WD (2013) Oligomeric states of the Shigella translocator protein IpaB provide structural insights into formation of the type III secretion translocon. Protein Sci 22(5):614-627. https://doi.org/10.1002/pro.2245

Ferrari ML, Charova SN, Sansonetti PJ, Mylonas E, Gazi AD (2021) Structural insights of Shigella translocator IpaB and its chaperone IpgC in solution. Front Cell Infect Microbiol 11:673122. https:// doi.org/10.3389/fcimb.2021.673122

Frenck RW Jr, Baqar S, Alexander W, Dickey M, McNeal M, ElKhorazaty J, Baughman H, Hoeper A, Barnoy S, Suvarnapunya AE, Kaminski RW, Venkatesan MM (2018) A phase I trial to evaluate the safety and immunogenicity of WRSs2 and WRSs3; two live oral candidate vaccines against Shigella sonnei. Vaccine 36(32 Pt B):4880-4889. https://doi.org/10.1016/j.vaccine.2018. 06.063

Gao NJ, Uchiyama S, Pill L, Dahesh S, Olson J, Bautista L, Maroju S, Berges A, Liu JZ, Zurich RH, van Sorge NM, Fairman J, Kapoor N, Nizet V (2021) Site-specific conjugation of cell wall polyrhamnose to protein SpyAD envisioning a safe universal group A streptococcal vaccine. Infect Microb \& Dis 3(2):87-100. https:// doi.org/10.1097/im9.0000000000000044

Guichon A, Hersh D, Smith MR, Zychlinsky A (2001) Structure-function analysis of the Shigella virulence factor IpaB. J Bacteriol 183(4):1269-1276. https://doi.org/10.1128/JB.183.4.1269-1276. 2001

Guris D, Strebel PM, Jafari H, Wharton M, Hadler SC (1997) Pertussis vaccination : use of acellular pertussis vaccines among infants and young children : recommendations of the advisory committee on immunization practices (ACIP). MMWR Recomm Rep : morbidity and mortality weekly report recommendations and reports / centers for disease control 1997 46(RR-7):1-25 46

Heine SJ, Diaz-McNair J, Andar AU, Drachenberg CB, van de Verg L, Walker R, Picking WL, Pasetti MF (2014) Intradermal delivery of Shigella IpaB and IpaD type III secretion proteins: kinetics of cell recruitment and antigen uptake, mucosal and systemic immunity, and protection across serotypes. J Immunol 192(4):1630-1640. https://doi.org/10.4049/jimmunol.1302743

Heine SJ, Diaz-McNair J, Martinez-Becerra FJ, Choudhari SP, Clements JD, Picking WL, Pasetti MF (2013) Evaluation of immunogenicity and protective efficacy of orally delivered Shigella type III secretion system proteins IpaB and IpaD. Vaccine 31(28):2919-2929. https://doi.org/10.1016/j.vaccine.2013.04.045

Heine SJ, Franco-Mahecha OL, Chen X, Choudhari S, Blackwelder WC, van Roosmalen ML, Leenhouts K, Picking WL, Pasetti MF (2015) Shigella IpaB and IpaD displayed on L. lactis bacteriumlike particles induce protective immunity in adult and infant mice. Immunol Cell Biol 93(7):641-652. https://doi.org/10.1038/icb. 2015.24

Hume PJ, McGhie EJ, Hayward RD, Koronakis V (2003) The purified Shigella IpaB and Salmonella SipB translocators share biochemical properties and membrane topology. Mol Microbiol 49(2):425439. https://doi.org/10.1046/j.1365-2958.2003.03559.x

Jewett MC, Swartz JR (2004) Mimicking the Escherichia coli cytoplasmic environment activates long-lived and efficient cell-free protein synthesis. Biotechnol Bioeng 86(1):19-26. https://doi.org/ 10.1002/bit.20026

Kapoor N, Vanjak I, Rozzelle J, Berges A, Chan W, Yin G, Tran C, Sato AK, Steiner AR, Pham TP, Birkett AJ, Long CA, Fairman J, Miura K (2018) Malaria derived glycosylphosphatidylinositol anchor enhances anti-Pfs 25 functional antibodies that block malaria transmission. Biochemistry 57(5):516-519. https://doi. org/10.1021/acs.biochem.7b01099

Khalil IA, Troeger C, Blacker BF, Rao PC, Brown A, Atherly DE, Brewer TG, Engmann CM, Houpt ER, Kang G, Kotloff KL, Levine MM, Luby SP, MacLennan CA, Pan WK, Pavlinac PB, PlattsMills JA, Qadri F, Riddle MS et al (2018) Morbidity and mortality due to Shigella and enterotoxigenic Escherichia coli diarrhoea: the Global Burden of Disease Study 1990-2016. Lancet Infect Dis 18(11):1229-1240. https://doi.org/10.1016/s1473-3099(18) 30475-4

Kim DM, Swartz JR (2004) Efficient production of a bioactive, multiple disulfide-bonded protein using modified extracts of Escherichia coli. Biotechnol Bioeng 85(2):122-129. https://doi.org/10. 1002/bit.10865

Kotloff KL, Losonsky GA, Nataro JP, Wasserman SS, Hale TL, Taylor DN, Newland JW, Sadoff JC, Formal SB, Levine MM (1995) Evaluation of the safety, immunogenicity, and efficacy in healthy adults of four doses of live oral hybrid Escherichia coli-Shigella flexneri $2 a$ vaccine strain EcSf2a-2. Vaccine 13(5):495-502. https://doi.org/10.1016/0264-410x(94)00011-b

Kotloff KL, Nasrin D, Blackwelder WC, Wu Y, Farag T, Panchalingham S, Sow SO, Sur D, Zaidi AKM, Faruque ASG, Saha D, Alonso PL, Tamboura B, Sanogo D, Onwuchekwa U, Manna B, Ramamurthy T, Kanungo S, Ahmed S et al (2019) The incidence, aetiology, and adverse clinical consequences of less severe diarrhoeal episodes among infants and children residing in lowincome and middle-income countries: a 12-month case-control study as a follow-on to the Global Enteric Multicenter Study (GEMS). Lancet Glob Health 7(5):e568-e584. https://doi.org/ 10.1016/S2214-109X(19)30076-2

Kotloff KL, Pasetti MF, Barry EM, Nataro JP, Wasserman SS, Sztein MB, Picking WD, Levine MM (2004) Deletion in the Shigella enterotoxin genes further attenuates Shigella flexneri $2 a$ bearing guanine auxotrophy in a phase 1 trial of CVD 1204 and CVD 1208. J Infect Dis 190(10):1745-1754. https://doi.org/10.1086/ 424680

Lindsay B, Ochieng JB, Ikumapayi UN, Toure A, Ahmed D, Li S, Panchalingam S, Levine MM, Kotloff K, Rasko DA, Morris CR, Juma J, Fields BS, Dione M, Malle D, Becker SM, Houpt ER, Nataro JP, Sommerfelt H et al (2013) Quantitative PCR for detection of Shigella improves ascertainment of Shigella burden in children with moderate-to-severe diarrhea in low-income countries. J Clin Microbiol 51(6):1740-1746. https://doi.org/10.1128/JCM. 02713-12

Liu J, Platts-Mills JA, Juma J, Kabir F, Nkeze J, Okoi C, Operario DJ, Uddin J, Ahmed S, Alonso PL, Antonio M, Becker SM, Blackwelder WC, Breiman RF, Faruque AS, Fields B, Gratz J, Haque $\mathrm{R}$, Hossain A et al (2016) Use of quantitative molecular diagnostic methods to identify causes of diarrhoea in children: a reanalysis of the GEMS case-control study. Lancet 388(10051):1291-1301. https://doi.org/10.1016/s0140-6736(16)31529-x

Livio S, Strockbine NA, Panchalingam S, Tennant SM, Barry EM, Marohn ME, Antonio M, Hossain A, Mandomando I, Ochieng JB, Oundo JO, Qureshi S, Ramamurthy T, Tamboura B, Adegbola RA, Hossain MJ, Saha D, Sen S, Faruque AS et al (2014) Shigella isolates from the global enteric multicenter study inform vaccine development. Clin Infect Dis 59(7):933-941. https://doi.org/10. 1093/cid/ciu468

Lokareddy RK, Lunelli M, Eilers B, Wolter V, Kolbe M (2010) Combination of two separate binding domains defines stoichiometry between type III secretion system chaperone IpgC and translocator protein IpaB. J Biol Chem 285(51):39965-39975. https://doi.org/ 10.1074/jbc.M110.135616

Martinez-Becerra FJ, Chen X, Dickenson NE, Choudhari SP, Harrison K, Clements JD, Picking WD, Van De Verg LL, Walker RI, Picking WL (2013a) Characterization of a novel fusion protein 
from IpaB and IpaD of Shigella spp. and its potential as a panShigella vaccine. Infect Immun 81(12):4470-4477. https://doi.org/ 10.1128/IAI.00859-13

Martinez-Becerra FJ, Kissmann JM, Diaz-McNair J, Choudhari SP, Quick AM, Mellado-Sanchez G, Clements JD, Pasetti MF, Picking WL (2012) Broadly protective Shigella vaccine based on type III secretion apparatus proteins. Infect Immun 80(3):1222-1231. https://doi.org/10.1128/IAI.06174-11

Martinez-Becerra FJ, Scobey M, Harrison K, Choudhari SP, Quick AM, Joshi SB, Middaugh CR, Picking WL (2013b) Parenteral immunization with IpaB/IpaD protects mice against lethal pulmonary infection by Shigella. Vaccine 31(24):2667-2672. https:// doi.org/10.1016/j.vaccine.2013.04.012

Mattock E, Blocker AJ (2017) How Do the Virulence Factors of Shigella Work Together to Cause Disease? Front Cell Infect Microbiol 7:64. https://doi.org/10.3389/fcimb.2017.00064

Ménard R, Sansonetti P, Parsot C, Vasselon T (1994) Extracellular association and cytoplasmic partitioning of the IpaB and IpaC invasins of S. flexneri. Cell 79(3):515-525. https://doi.org/10. 1016/0092-8674(94)90260-7

Ndungo E, Randall A, Hazen TH, Kania DA, Trappl-Kimmons K, Liang X, Barry EM, Kotloff KL, Chakraborty S, Mani S, Rasko DA, Pasetti MF (2018) A novel Shigella proteome microarray discriminates targets of human antibody reactivity following oral vaccination and experimental challenge. mSphere 3(4):e00260e00218. https://doi.org/10.1128/mSphere.00260-18

Noriega FR, Liao FM, Maneval DR, Ren S, Formal SB, Levine MM (1999) Strategy for cross-protection among Shigella serotypes. Infect Immun 67(2):782-788. https://doi.org/10.1128/iai.67.2. 782-788.1999

Noriega FR, Losonsky G, Lauderbaugh C, Liao FM, Wang JY, Levine MM (1996) Engineered deltaguaB-A deltavirG Shigella $2 a$ strain CVD 1205: construction, safety, immunogenicity, and potential efficacy as a mucosal vaccine. Infect Immun 64(8):3055-3061. https://doi.org/10.1128/iai.64.8.3055-3061.1996

Oaks EV, Hale TL, Formal SB (1986) Serum immune response to Shigella protein antigens in rhesus monkeys and humans infected with Shigella spp. Infect Immun 53(1):57-63. https://doi.org/10. 1128/iai.53.1.57-63.1986

Oaks EV, Turbyfill KR (1992) Myosin-cross-reactive epitope of Shigella flexneri invasion plasmid antigen B. Infect Immun 60(2):557-564. https://doi.org/10.1128/iai.60.2.557-564.1992

Oberhelman RA, Kopecko DJ, Salazar-Lindo E, Gotuzzo E, Buysse JM, Venkatesan MM, Yi A, Fernandez-Prada C, Guzman M, Leon-Barua R (1991) Prospective study of systemic and mucosal immune responses in dysenteric patients to specific Shigella invasion plasmid antigens and lipopolysaccharides. Infect Immun 59(7):2341-2350. https://doi.org/10.1128/iai.59.7.2341-2350. 1991

Passwell JH, Ashkenazi S, Banet-Levi Y, Ramon-Saraf R, Farzam N, Lerner-Geva L, Even-Nir H, Yerushalmi B, Chu C, Shiloach J, Robbins JB, Schneerson R (2010) Age-related efficacy of Shigella $\mathrm{O}$-specific polysaccharide conjugates in 1-4-year-old Israeli children. Vaccine 28(10):2231-2235. https://doi.org/10.1016/j.vacci ne. 2009.12 .050

Picking WL, Mertz JA, Marquart ME, Picking WD (1996) Cloning, expression, and affinity purification of recombinant Shigella flexneri invasion plasmid antigens IpaB and IpaC. Protein Expr Purif 8(4):401-408. https://doi.org/10.1006/prep.1996.0117

Picking WL, Picking WD (2016) The Many Faces of IpaB. Front Cell Infect Microbiol 6:12. https://doi.org/10.3389/fcimb.2016.00012

Rappuoli R (2018) Glycoconjugate vaccines: Principles and mechanisms. Sci Transl Med 10(456):eaat4615. https://doi.org/10.1126/ scitranslmed.aat 4615
Riddle MS, Kaminski RW, Williams C, Porter C, Baqar S, Kordis A, Gilliland T, Lapa J, Coughlin M, Soltis C, Jones E, Saunders J, Keiser PB, Ranallo RT, Gormley R, Nelson M, Turbyfill KR, Tribble D, Oaks EV (2011) Safety and immunogenicity of an intranasal Shigella $2 a$ Invaplex 50 vaccine. Vaccine 29(40):70097019. https://doi.org/10.1016/j.vaccine.2011.07.033

Robin G, Cohen D, Orr N, Markus I, Slepon R, Ashkenazi S, Keisari Y (1997) Characterization and quantitative analysis of serum IgG class and subclass response to Shigella sonnei and Shigella $2 a$ lipopolysaccharide following natural Shigella infection. J Infect Dis 175(5):1128-1133. https://doi.org/10.1086/516452

Rohde JR, Breitkreutz A, Chenal A, Sansonetti PJ, Parsot C (2007) Type III secretion effectors of the IpaH family are E3 ubiquitin ligases. Cell Host Microbe 1(1):77-83. https://doi.org/10.1016/j. chom.2007.02.002

Sahl JW, Morris CR, Emberger J, Fraser CM, Ochieng JB, Juma J, Fields B, Breiman RF, Gilmour M, Nataro JP, Rasko DA (2015) Defining the phylogenomics of Shigella species: a pathway to diagnostics. J Clin Microbiol 53(3):951-960. https://doi.org/10. 1128/JCM.03527-14

Schnupf P, Sansonetti PJ (2019) Shigella Pathogenesis: New Insights through Advanced Methodologies. Microbiol Spectr 7(2):7-2. https://doi.org/10.1128/microbiolspec.BAI-0023-2019

Schroeder GN, Hilbi H (2008) Molecular pathogenesis of Shigella spp.: controlling host cell signaling, invasion, and death by type III secretion. Clin Microbiol Rev 21(1):134-156. https://doi.org/10. 1128/CMR.00032-07

Shen DK, Saurya S, Wagner C, Nishioka H, Blocker AJ (2010) Domains of the Shigella flexneri type III secretion system IpaB protein involved in secretion regulation. Infect Immun 78(12):4999-5010. https://doi.org/10.1128/iai.00470-10

Sheng J, Lei S, Yuan L, Feng X (2017) Cell-free protein synthesis of norovirus virus-like particles. RSC Adv 7:28837-28840. https:// doi.org/10.1039/c7ra03742b

Shimanovich AA, Buskirk AD, Heine SJ, Blackwelder WC, Wahid R, Kotloff KL, Pasetti MF (2017) Functional and antigen-specific serum antibody levels as correlates of protection against shigellosis in a controlled human challenge study. Clin Vaccine Immunol 24(2):e00412-e00416. https://doi.org/10.1128/CVI.00412-16

Singer AU, Rohde JR, Lam R, Skarina T, Kagan O, Dileo R, Chirgadze NY, Cuff ME, Joachimiak A, Tyers M, Sansonetti PJ, Parsot C, Savchenko A (2008) Structure of the Shigella T3SS effector IpaH defines a new class of E3 ubiquitin ligases. Nat Struct Mol Biol 15(12):1293-1301. https://doi.org/10.1038/nsmb.1511

Turbyfill KR, Clarkson KA, Vortherms AR, Oaks EV, Kaminski RW (2018) Assembly, biochemical characterization, immunogenicity, adjuvanticity, and efficacy of Shigella artificial invaplex. mSphere 3(2):e00583-e00517. https://doi.org/10.1128/mSphere.00583-17

Van de Verg LL, Herrington DA, Boslego J, Lindberg AA, Levine MM (1992) Age-specific prevalence of serum antibodies to the invasion plasmid and lipopolysaccharide antigens of Shigella species in chilean and north american populations. J Infect Dis 166(1):158-161. https://doi.org/10.1093/infdis/166.1.158

Venkatesan MM, Buysse JM, Kopecko DJ (1989) Use of Shigella flexneri ipaC and ipaH gene sequences for the general identification of Shigella spp. and enteroinvasive escherichia coli. J Clin Microbiol 27(12):2687-2691. https://doi.org/10.1128/jcm.27.12. 2687-2691.1989

Vu DT, Sethabutr O, Von Seidlein L, Tran VT, Do GC, Bui TC, Le HT, Lee H, Houng HS, Hale TL, Clemens JD, Mason C, Dang DT (2004) Detection of Shigella by a PCR assay targeting the ipaH gene suggests increased prevalence of shigellosis in Nha Trang, Vietnam. J Clin Microbiol 42(5):2031-2035. https://doi.org/10. 1128/jcm.42.5.2031-2035.2004 
Walker R, Kaminski RW, Porter C, Choy RKM, White JA, Fleckenstein JM, Cassels F, Bourgeois L (2021) Vaccines for protecting infants from bacterial causes of diarrheal disease. Microorganisms 9(7):1382. https://doi.org/10.3390/microorganisms9071382

Xu Y, Lee J, Tran C, Heibeck TH, Wang WD, Yang J, Stafford RL, Steiner AR, Sato AK, Hallam TJ, Yin G (2015) Production of bispecific antibodies in "knobs-into-holes" using a cell-free expression system. MAbs 7(1):231-242. https://doi.org/10.4161/ 19420862.2015.989013

Ye Y, Xiong Y, Huang H (2020) Substrate-binding destabilizes the hydrophobic cluster to relieve the autoinhibition of bacterial ubiquitin ligase IpaH9.8. Commun Biol 3(1):752. https://doi.org/10. 1038/s42003-020-01492-1

Yin G, Garces ED, Yang J, Zhang J, Tran C, Steiner AR, Roos C, Bajad S, Hudak S, Penta K, Zawada J, Pollitt S, Murray CJ (2012) Aglycosylated antibodies and antibody fragments produced in a scalable in vitro transcription-translation system. MAbs 4(2):217225. https://doi.org/10.4161/mabs.4.2.19202

Zawada JF, Yin G, Steiner AR, Yang J, Naresh A, Roy SM, Gold DS, Heinsohn HG, Murray CJ (2011) Microscale to manufacturing scale-up of cell-free cytokine production--a new approach for shortening protein production development timelines. Biotechnol Bioeng 108(7):1570-1578. https://doi.org/10.1002/bit.23103

Zichel R, Mimran A, Keren A, Barnea A, Steinberger-Levy I, Marcus D, Turgeman A, Reuveny S (2010) Efficacy of a potential trivalent vaccine based on $\mathrm{Hc}$ fragments of botulinum toxins $\mathrm{A}, \mathrm{B}$, and $\mathrm{E}$ produced in a cell-free expression system. Clin Vaccine Immunol 17(5):784-792. https://doi.org/10.1128/cvi.00496-09

Publisher's note Springer Nature remains neutral with regard to jurisdictional claims in published maps and institutional affiliations. 